\title{
DETERMINAN KEJADIAN DEMAM BREDARAH DENGUE (DBD) DI WILAYAH KERJA PUSKESMAS HARAPAN RAYA
}

\author{
Wenni Ardianti ${ }^{1}$, Buchari Lapau ${ }^{2}$, Oktavia Dewi ${ }^{2}$ \\ 1. Mahasiswa Prodi Magister Kesehatan Masyarakat STIKes Hang Tuah Pekanbaru, Riau, \\ Indonesia \\ 2. Dosen Prodi Magister Kesehatan Masyarakat STIKes Hang Tuah Pekanbaru, Riau, \\ Indonesia \\ Email :wenniardhi88@gmail.com
}

\begin{abstract}
Abstrak
Penyakit DBD adalah penyakit menular yang disebabkan oleh virus dengue dan ditularkan oleh nyamuk Aedes aegypti, dan masih menjadi masalah kesehatan masyarakat. Di wilayah kerja Puskesmas Harapan Raya pada tahun 2017 terjadi sebanyak 98 kasus ( IR = 85,0 per 100.000 penduduk) dan sudah melebihi batas endemisitas Indonesia yaitu $\leq 49$ per 100.000 penduduk. Tujuan penelitian adalah diketahuinya determinan kejadian DBD di wilayah kerja Puskesmas Harapan Raya tahun 2015-2017. Desain penelitian adalah Studi Kasus Kontrol Unmatch. Populasi kasus adalah seluruh penderita DBD dari tahun 2015-2017 yang berjumlah 228 orang dan populasi kontrol adalah seluruh kasus yang bukan DBD pada bulan yang sama saat terjadi penyakit DBD tahun 2017 yang berjumlah 8.529 orang. Jumlah sampel 180 kasus dan 180 kontrol. Data dianalisis secara univariat, bivariat dan multivariat. Hasil analisis multivariat, variabel yang paling berpengaruh adalah umur (CI 95\% $=7,889$ 38,224), keberadaan sampah (CI 95\% = 1,750-5,069), tidak melakukan 3M berisiko (CI 95\% $=2,226-6,243)$, kebiasaan tidur pagi/sore (CI 95\% = 1,019- 2,877), tidak memiliki kawat kasa pada ventilasi (CI 95\% $=1,268-3,571)$. Disarankan masyarakat memakai obat anti nyamuk, menyediakan tempat sampah yang tertutup, menggunakan kawat kasa dan melakukan 3M minimal 1x seminggu. Pihak puskesmas untuk melakukan penyuluhan cara mengolah sampah yang padat dengan baik dan benar serta pentingnya melakukan $3 \mathrm{M}$ sekali seminggu.
\end{abstract}

Kata Kunci : DBD, keberadaan sampah, Puskesmas Harapan Raya, Kawat Kasa Pekanbaru 2018

\section{PENDAHULUAN}

Penyakit Demam Berdarah Dengue (DBD) adalah penyakit menular yang disebabkan oleh virus dengue dan ditularkan oleh nyamuk Aedes aegypti, yang ditandai dengan demam mendadak 2 sampai dengan 7 hari tanpa penyebab yang jelas, lemah/lesu, gelisah, nyeri ulu hati, disertai tanda perdarahan di kulit berupa bintik perdarahan (petechiae, lebam (echymosis) atau ruam (purapura). Kadang-kadang mimisan, berak darah, muntah darah, kesadaran menurun atau renjatan (Shock) (Kemenkes RI, 2011).

Diperkirakan sekitar 2,9 juta kasus demam berdarah dengue dengan 5.906 kematian terjadi di Asia Tenggara setiap tahunnya (Ariani, Ayu Putri, 2016). Di Indonesia pada tahun 2014 jumlah penderita DBD yang dilaporkan sebanyak 100.347 kasus dengan jumlah kematian sebanyak 907 orang (Incidence Rate (IR) = 39,8 per 100.000 penduduk dan Case Fatality Rate $(\mathrm{CFR})=0,9 \%)$. Sedangkan pada tahun 2015 terjadi sebanyak 129.650 
kasus dengan jumlah kematian 1.071 orang $(\mathrm{IR}=50,75$ per 100.000 penduduk dan CFR $=0,83 \%)$. Dan untuk tahun 2016, kasus DBD di Indonesia terjadi sebanyak 204.171 kasus dengan jumlah kematian $1.598(\mathrm{IR}=78,85$ per 100.000 penduduk dan CFR $=0,78 \%$ ) (Kemenkes RI, 2016).

Di Provinsi Riau, jumlah kasus DBD yang dilaporkan pada tahun 2014 sebanyak 2.342 kasus dan meninggal sebanyak 31 orang ( $\mathrm{IR}=36,83$ per 100.000 penduduk dan $\mathrm{CFR}=1,32 \%$ ). Sedangkan untuk tahun 2015 terjadi sebanyak 3.261 kasus dan meninggal sebanyak 22 orang (IR = 51,40 per 100.000 penduduk, $\mathrm{CFR}=$ 0,67\%). Pada tahun 2016 terjadi sebanyak 4.170 kasus dan meninggal sebanyak 39 orang (IR $=64,14$ per 100.000 penduduk, CFR $=0,94 \%)$ (Kemenkes RI, 2016).

Di Kota Pekanbaru untuk tahun 2014 terjadi 209 kasus dan terdapat 5 kasus meninggal akibat DBD dengan (IR $=19,9$ per 100.000 penduduk dan $\mathrm{CFR}=2,4 \%$ ). Sedangkan tahun 2015 terjadi sebanyak 516 kasus dan terdapat 4 orang meninggal (IR $=49,7$ per 100.000 penduduk dan CFR $=0,77 \%$ ). Untuk tahun 2016 jumlah kasus DBD sebanyak 873 kasus dengan kasus yang meninggal sebanyak 10 orang (IR = 82 per 100.000 penduduk, $\mathrm{CFR}=1,1 \%$ ) (Dinkes Kota Pekanbaru, 2016).

Faktor-faktor risiko yang dapat mempengaruhi terjadinya penyakit demam berdarah diantaranya: lingkungan rumah (jarak rumah dan kondisi tempat penampungan air), lingkungan biologi (tanaman hias, tanaman pekarangan yang mempengaruhi kelembaban serta keberadaan jentik), lingkungan sosial (kebiasaan menggantung baju, kebiasaan tidur siang, partisipasi masyarakat dalam pembersihan sarang nyamuk). Faktor lain yang dapat mempengaruhi kejadian demam beradarah dengue diantaranya: karakteristik penduduk (umur, jenis kelamin, pendidikan dan pekerjaan), lingkungan sosial (kebiasaan menggunakan obat anti nyamuk, menggunakan kawat kasa pada ventilasi) dan lingkungan rumah (keberadaan barang bekas yang dapat menampung air) (Prasetyani, 2015; Sitio A, 2008).

Berdasarkan data dari Puskesmas Harapan Raya pada tahun 2015 terjadi sebanyak 42 kasus (IR $=38,2$ per 100.000 penduduk). Pada tahun 2016 kasus DBD terjadi sebanyak 88 kasus dengan jumlah kematian 1 orang (IR = 80,19 per 100.000 penduduk, $\mathrm{CFR}=1,1 \%$ ). Lalu pada tahun 2017 terjadi sebanyak 98 kasus ( IR $=85,0$ per 100.000 penduduk). Berdasarkan batas endemisitas Indonesia untuk angka kesakitan DBD tahun 2016 sebesar $\leq 49$ per 100.000 penduduk. Dengan demikian pada tahun 2017 Puskesmas Harapan Raya melebihi batas endemisitas Indonesia (Dinkes Kota Pekanbaru, 2016).

Tujuan penelitian ini adalah untuk mengetahui Determinan Kejadian Demam Berdarah Dengue (DBD) di Wilayah Kerja Puskesmas Harapan Raya tahun 2015-2017. Manfaat sosial penelitian ini adalah untuk memperoleh informasi dan masukan untuk perencanaan pemberantasan penyakit Demam Berdarah Dengue (DBD) pada program pemberantasan penyakit DBD dalam rangka pencegahan penyakit DBD di wilayah kerja Puskesmas Harapan Rayadan manfaat ilmiah adalah hasil penelitian ini dapat menambah ilmu pengetahuan dan pengembangan disiplin ilmu epidemiologi penyakit serta mendapatkan informasi untuk penelitian selanjutnya.

\section{METODE PENELITIAN}

Penelitian ini bersifat kuantitatif analitik observasional dengan desain case 
control unmacth study. Populasi kasus dalam penelitian ini adalah seluruh penderita DBD dari tahun 2015-2017 di wilayah kerja Puskesmas Harapan Raya dan tercatat di buku register DBD yang berjumlah 228 orang, sedangkan populasi kontrol yaitu seluruh kasus yang bukan DBD pada bulan yang sama saat terjadi penyakit DBD tahun 2017 yang berdomisili di wilayah kerja Puskesmas Harapan Raya yang berjumlah 8.529 orang. Kriteria inklusi kasus yang ditetapkan adalah Menderita DBD dari tahun 2015 sampai dengan tahun 2017 ditandai dengan hasil S0 positif dan tercatat di buku register DBD, mampu berkomunikasi dengan baik dan bersedia untuk diwawancarai, berdomisili di Kecamatan Bukit Raya dari tahun 20152017 dan apabila penderita berhalangan atau belum mencukupi umur, maka dapat diwakilkan oleh anggota keluarga dengan syarat berusia minimal 18 tahun. Kriteria inklusi kontrol adalah Responden yang tidak menderita DBD pada bulan yang sama terjadinya kasus DBD, mampu berkomunikasi dengan baik dan bersedia untuk diwawancarai serta bertempat tinggal di Kecamatan Bukit Raya tahun 2015-2017. Kriteria eksklusi kasus dan kontrol adalah orang yang menolak berpartisipasi (diwawancarai dan observasi), tidak berada di tempat saat penelitian. Sampel dalam penelitian ini terdiri dari sampel kasus dan sampel kontrol. Jumlah sampel pada penelitian ini adalah 180 kasus dan 180 kontrol. Pengambilan sampel kasus dan kontrol dilakukan secara systematic random sampling.

Pengumpulan data dalam penelitian ini menggunakan data primer dan data sekunder. Data primer diperoleh dengan melakukan wawancara dan observasi dengan menggunakan kuesioner, sedangkan data sekunder diperoleh dari buku register DBD Puskesmas Harapan Raya. Variabel-variabel yang digunakan adalah kejadian DBD sebagai variabel dependen dengan hasil ukur DBD dan tidak DBD, sedangkan variabel independen yaitu keberadaan sampah dengan hasil ukur ya ada sampah dan tidak ada sampah, keberadaan jentik dengan hasil ukur ya ada jentik dan tidak ada jentiktanaman hias dan tanaman pekarangan dengan hasil ukur ya ada tanaman rimbun dan tidak ada tanaman rimbun, melakukan $3 \mathrm{M}$ dengan hasil ukur tidak melakukan $3 \mathrm{M}$ dan melakukan $3 \mathrm{M}$, kebiasaan tidur pagi/sore hari dengan hasil ukur ya tidur pagi/sore hari dan tidak tidur pagi/sore hari, kebiasaan menggantung pakaian dengan hasil ukur ya menggantung pakaian dan tidak menggantung pakaian, kebiasaan menggunakan obat anti nyamuk dengan hasil ukur tidak menggunakan obat anti nyamuk dan ya menggunakan obat anti nyamuk, menggunakan kawat kasa pada ventilasi dengan hasil ukur tidak mengggunakan kawat kasa pada ventilasi dan menggunakan kawat kasa pada ventilasi, umur dengan hasil ukur $<12$ tahun dan $\geq 12$ tahun, jenis kelamin dengan hasil ukur perempuan dan laki-laki, pendidikan dengan hasil ukur rendah (SD/SMP/SMA) dan tinggi (PT),.

Pengolahan data meliputi Menyunting data (Editing), Mengkode data (Coding), Memasukkan data (Entry), Membersihkan data (Cleaning), dan Tabulasi data (Tabulating). Analisis data dilakukan secara univariat, bivariat dilakukan dengan uji Chi Square dan multivariat dengan menggunakan Regresi Logistik Ganda. 


\section{HASIL DAN PEMBAHASAN}

Hasil

\section{Analisis Univariat}

Hasil analisis univariat menunjukkan bahwa proporsi mereka yang mempunyai keberadaan jentik di sekitar rumah sebesar $66,7 \%$, mereka yang mempunyai keberadaan sampah di sekitar rumah sebanyak $62,5 \%$ dan mereka yang berpendidikan rendah sebesar 61,7\%, mereka yang tidak menggunakan kawat kasa pada ventilasi sebanyak $60 \%$, mereka yang berjenis kelamin perempuan sebanyak 60\%, mereka yang memiliki kebiasaan menggantung pakaian sebanyak $59,7 \%$, mereka yang memiliki kebiasaan tidur pagi/sore hari sebanyak 59,4\%, mereka yang memiliki tanaman hias dan tanaman pekarangan sebanyak 58,1\%, mereka yang memiliki kebiasaan tidak menggunakan obat anti nyamuk sebanyak $57,8 \%$, mereka yang tidak melakukan $3 \mathrm{M}$ sebanyak 55\%, mereka yang berumur $<12$ tahun sebanyak $40 \%$ serta tidak ada data yang homogen (semua kategori $>20 \%$ )

\section{Analisis Bivariat}

Hasil analisis bivariat menunjukkan ada 8 variabel independen yang berhubungan signifikan dengan kejadian DBD, mempunyai keberadaan sampah di sekitar rumah (CI 95\% : OR = 1,9-4,6), mempunyai keberadaan jentik di sekitar rumah (CI 95\% : OR = 1,06-2,5), tidak melakukan 3M (CI 95\%: OR = 2,1-5,1), melakukan kebiasaan tidur pagi/sore hari (CI 95\% : OR = 1,04-2,4), melakukan kebiasaan menggantung pakaian (CI 95\% : OR $=1,1-2,6)$, melakukan kebiasaan tidak menggunakan obat anti nyamuk (CI 95\% : $\mathrm{OR}=1,1-2,6)$, tidak menggunakan kawat kasa pada ventilasi (CI 95\%: OR $=1,3$ $3,1)$, berumur $<12$ tahun (CI 95\% : OR = $3,0-7,5)$.

Tabel 1 Hubungan Antara Variabel Independen Dan Variabel Dependen Dengan Kejadian Demam Berdarah Dengue (DBD) Di Wilayah Kerja Puskesmas Harapan Raya Tahun 2015-2017

\begin{tabular}{|c|c|c|c|c|c|c|c|c|c|}
\hline \multirow{3}{*}{ No. } & \multirow{3}{*}{ Variabel Independen } & \multicolumn{8}{|c|}{ Kejadian DBD } \\
\hline & & \multicolumn{2}{|c|}{ Kasus } & \multicolumn{2}{|c|}{ Kontrol } & \multicolumn{2}{|c|}{ Total } & \multirow{2}{*}{ Or } & \multirow{2}{*}{$\begin{array}{c}P \\
\text { Value }\end{array}$} \\
\hline & & n 180 & $\%$ & n 180 & $\%$ & $\mathbf{N}$ & $\%$ & & \\
\hline \multirow[t]{3}{*}{1} & Keberadaan Sampah & & & & & & & & \\
\hline & $-\quad \mathbf{Y a}$ & 135 & 75,0 & 90 & $\mathbf{5 0 , 0}$ & 225 & 62,5 & 3,000 & 0,000 \\
\hline & - $\quad$ Tidak & 45 & 25,0 & 90 & $\mathbf{5 0 , 0}$ & 135 & 37,5 & $(1,92-4,68)$ & \\
\hline \multirow[t]{3}{*}{2} & Keberadaan Jentik & & & & & & & & \\
\hline & $-\quad \mathbf{Y a}$ & 130 & 72,2 & 110 & 61,1 & 240 & 66,7 & 1,655 & $\mathbf{0 , 0 3 3}$ \\
\hline & - $\quad$ Tidak & 50 & 27,8 & 70 & 38,9 & 120 & $\mathbf{3 3 , 3}$ & $(1,06-2,57)$ & \\
\hline \multirow[t]{3}{*}{3} & $\begin{array}{l}\text { Tanaman hias dan tanaman } \\
\text { pekarangan }\end{array}$ & & & & & & & & \\
\hline & $-\quad \mathrm{Ya}$ & 112 & 62,2 & 97 & 53,9 & 209 & 58,1 & 1,409 & 0,135 \\
\hline & - Tidak & 68 & 37,8 & 83 & 46,1 & 151 & 41,9 & $(0,92-2,14)$ & \\
\hline \multirow[t]{3}{*}{4} & Melakukan 3M & & & & & & & & \\
\hline & - Tidak & 125 & 69,4 & 73 & 40,6 & 198 & $\mathbf{5 5 , 0}$ & $\mathbf{3 , 3 3 1}$ & 0,000 \\
\hline & $-\quad \mathbf{Y a}$ & 55 & 30,6 & 107 & 59,4 & 162 & 45,0 & $(2,15-5,14)$ & \\
\hline \multirow[t]{3}{*}{5} & $\begin{array}{l}\text { Kebiasaan tidur pagi/sore } \\
\text { hari }\end{array}$ & & & & & & & & \\
\hline & $-\quad \mathbf{Y a}$ & 117 & 65,0 & 97 & 53,9 & 214 & $\mathbf{5 9 , 4}$ & 1,589 & 0,041 \\
\hline & - $\quad$ Tidak & 63 & 35,0 & 83 & 46,1 & 146 & 40,6 & $(1,04-2,42)$ & \\
\hline \multirow[t]{2}{*}{6} & $\begin{array}{l}\text { Kebiasaan menggantung } \\
\text { pakaian }\end{array}$ & & & & & & & & \\
\hline & $-\quad \mathbf{Y a}$ & 119 & 66,1 & 96 & 53,3 & 215 & $\mathbf{5 9 , 7}$ & 1,707 & 0,018 \\
\hline
\end{tabular}




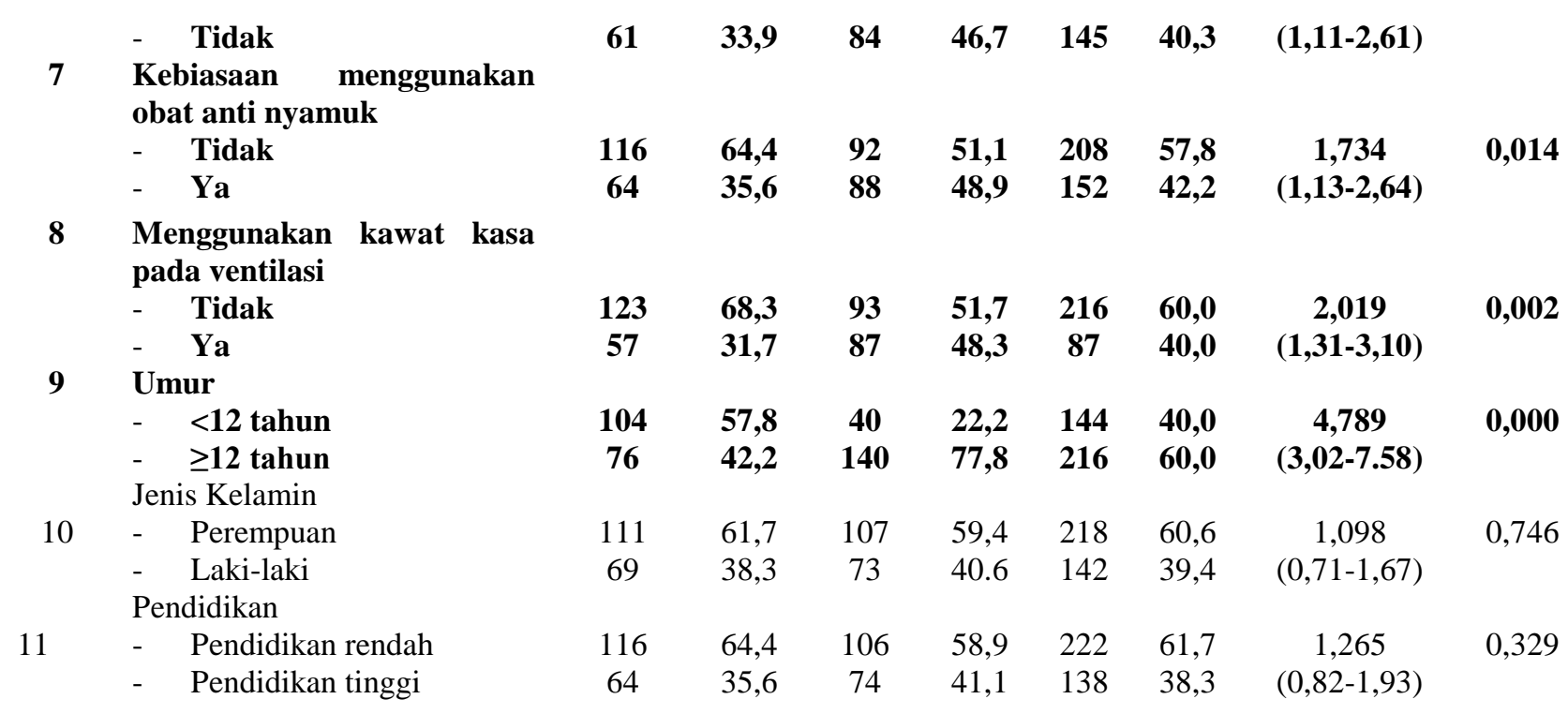

\section{Analisis Multivariat}

Hasil analisis multivariat dapat disimpulkan bahwa variabel independen yang dominan adalah keberadaan sampah,

3M, kebiasaan tidur pagi/sore hari, kawat kasa pada venrtilasi dan umur. Sedangkan pendidikan memiliki hubungan terbalik dengan DBD.

Tabel 2 Pemodelan Multivariat Akhir

\begin{tabular}{cccccc}
\hline No & Variabel & P Value & Exp $(\boldsymbol{B})$ & \multicolumn{2}{c}{ 95\% CI For EXP $(\boldsymbol{B})$} \\
& & & & Lower & Upper \\
\hline 1 & Keberaaan sampah &, 000 & 2,978 & 1,750 & 5,069 \\
2 & 3M &, 000 & 3,728 & 2,226 & 6,243 \\
3 & Kebiasaan tidur pagi/sore hari &, 042 & 1,712 & 1,019 & 2,877 \\
4 & Kawat kasa pada Ventilasi &, 004 & 2,128 & 1,268 & 3,571 \\
5 & Umur &, 000 & 17,365 & 7,889 & 38,224 \\
6 & Pendidikan &, 000 &, 162 &, 075 &, 350 \\
Omnibus test of model coeffisient & & Nagelkerke $\boldsymbol{R}$ Square $=\mathbf{0 , 4 0 8}$ &
\end{tabular}

\section{Pembahasan}

\section{Hubungan Umur dengan Kejadian DBD}

Dalam penelitian ini umur berhubungan sebab akibat dengan kejadian DBD. mereka berumur $<12$ tahun berpengaruh 17,3 kali menderita DBD bila dibandingkan dengan mereka berumur $\geq$ 12 tahun. Mereka yang berumur $<12$ tahun lebih banyak menderita DBD dibandingkan dengan mereka yang berumur $\geq 12$ tahun. Hasil penelitian ini sejalan dengan hasil penelitian Darjito E
(2008) bahwa mereka yang berumur <12 tahun berisiko 19,05 kali lebih besar untuk terserang DBD dibandingkan mereka yang berumur $\geq 12$ tahun $(p<0,05)$. Kelompok umur $<12$ tahun merupakan kelompok umur yang paling banyak terinfeksi virus dengue. Umur <12 tahun akan mempengaruhi terhadap penularan penyakit DBD. Lebih banyak golongan umur <12 tahun berarti meningkatkan risiko untuk terjadinya penyakit DBD (Darjito E, 2008). Ditemukan teori yang 
mendukung yaitu kelompok umur $<12$ tahun memiliki daya tahan tubuh yang masih rendah dibandingkan kelompok umur yang lebih tua, sedangkan aktivitasnya sering bermain atau sekolah, dimana selama beberapa jam atau bahkan hampir seharian berada di dalam kondisi dan waktu yang meningkatkan risiko terkena gigitan nyamuk penular DBD bahkan multibiting yang juga dapat meningkatkan risiko terkena infeksi sekunder sehingga meningkatkan risiko terkena DBD (Umaya, 2013). Oleh karena itu, direkomendasikan responden yang berumur $<12$ tahun agar tidak beraktifitas atau bermain di tempat yang banyak nyamuk.

\section{Hubungan Melakukan 3M dengan Kejadian DBD}

Dalam penelitian ini melakukan $3 M$ berhubungan sebab akibat dengan kejadian $D B D$. Mereka yang tidak melakukan $3 \mathrm{M}$ berpengaruh 3,7 kali menderita DBD bila dibandingkan dengan mereka yang melakukan 3M. Mereka yang tidak melakukan 3M lebih banyak menderita DBD dibandingkan dengan mereka yang melakukan 3M. Penelitian ini sejalan dengan penelitian yang dilakukan oleh Carundeng M, dkk (2015) ada hubungan antara tindakan mengguras tempat penampungan air, menutup tempat penampungan air, tindakan mengubur barang bekas dengan kejadian DBD di Puskesmas Gogangoman Kota Kotamobangu tahun 2015 ( $\mathrm{p}<0,05$ ). Berdasarkan penelitian Lumingas, dkk, 2017 bahwa ada hubungan antara praktik menguras TPA, praktik menutup TPA, dan mengubur barang bekas dengan kejadian DBD di wilayah kerja Puskesmas Tanawangko tahun 2017 ( $\mathrm{p}<0,05)$. Melakukan 3M berpengaruh terhadap terjadinya kejadian DBD. Hal ini disebabkan pengurasan tempat-tempat penampungan air perlu dilakukan secara teratur sekurang-kurangnya seminggu sekali agar nyamuk tidak dapat berkembang biak. Selain pengurasan bak penampungan air, dalam tata laksana $3 \mathrm{M}$ juga harus diperhatikan ketersediaan tutup tempat penampungan air untuk menekan jumlah nyamuk yang hinggap pada tempat penampungan air, tempat penampungan air tersebut menjadi media berkembang biaknya nyamuk Aedes Aegypti. Ketersediaan tutup tempat penampungan air meliputi drum dan ember. Dan yang terakhir mengubur barang bekas sehingga tidak dapat menampung air hujan dan dijadikan tempat nyamuk bertelur (Fakhriadi R, dkk, 2015). Oleh karena itu direkomendasikan agar melakukan 3M minimal sekali dalam seminggu.

\section{Hubungan Keberadaan Sampah dengan Kejadian DBD}

Dalam penelitian ini ditemukan bahwa keberadaan sampah berhubungan sebab akibat dengan kejadian DBD. Responden yang mempunyai keberadaan sampah di sekitar rumah berpengaruh 2,9 kali menderita DBD bila dibandingkan dengan responden yang tidak mempunyai keberadaan sampah di sekitar rumah. Hasil penelitian ini sejalan dengan penelitian yang dilakukan Hasan, A (2008) di Bandar Lampung, keberadaan sampah yang dapat menampung air di sekitar rumah berisiko 2 kali lebih sering untuk kejadian penyakit DBD dengan $(p<0,05)$. Berdasarkan penelitian Wahyudi H (2015), diketahui bahwa ada hubungan yang signifikan antara keberadaan sampah yang dapat menampung air dengan kejadian DBD (CI 95\%: 1,660-10,919). Keberadaan sampah berpengaruh terhadap terjadinya kejadian 
DBD. Hal ini disebabkan ban, botol, plastik dan barang-barang lain yang dapat menampung air merupakan sarana yang memungkinkan untuk tempat perkembangbiakan nyamuk. Semakin banyak barang bekas (sampah) yang dapat menampung air, semakin banyak tempat bagi nyamuk untuk bertelur dan berkembang biak, sehingga semakin meningkat pula risiko kejadian DBD (Widodo 2012). Oleh karena itu, direkomendasikan agar tidak sembarangan membuang sampah yang dapat menampung air di sekitar rumah.

\section{Hubungan Menggunakan Kawat Kasa Pada Ventilasi dengan Kejadian DBD}

Hasil penelitian ini menunjukkan bahwa menggunakan kawat kasa pada ventilasi berhubungan sebab akibat dengan kejadian DBD. Mereka yang tidak menggunakan kawat kasa berpengaruh 2,1 kali menderita DBD bila dibandingkan dengan mereka yang menggunakan kawat kasa pada ventilasi. Peneltian ini sejalan dengan hasil penelitian Menurut penelitian Widodo N (2012) bahwa tidak menggunakan kawat kasa anti nyamuk mempunyai hubungan bermakna dengan kejadian DBD di Kota Mataram pada tahun 2012 dengan ( $\mathrm{p}<0,05)$. Menggunakan kawat kasa pada ventilasi berpengaruh terhadap terjadinya kejadian DBD. Hal ini disebabkan ventilasi adalah lubang tempat udara keluar masuk secara bebas. Ventilasi sebagai tempat pertukaran udara lubang pada ventilasi biasanya dimanfaatkan oleh nyamuk untuk ke luar maupun masuk ke dalam rumah. Sebaiknya masyarakat memasang kawat kasa pada lubang angin yang dapat dimanfaatkan oleh nyamuk untuk ke luar masuk ke rumah seperti ventilasi jendela maupun pintu (Amrieds Elvin,dkk, 2016).
Oleh karena itu, direkomendasikan bagi rumah yang luas ventilasinya tidak memenuhi syarat $(<10 \%)$, agar membuka jendela setiap hari agar setiap ventilasi rumah harus terpasang kawat kasa dengan baik.

\section{Hubungan Kebiasaan Tidur Pagi/Sore Hari dengan Kejadian DBD}

Dalam penelitian ini, kebiasaan tidur pagi/ sore hari berhubungan sebab akibat dengan kejadian DBD. Mereka yang melakukan kebiasaan tidur pagi/sore hari berpengaruh 1,7 kali menderita DBD bila dibandingkan dengan mereka yang tidak melakukan kebiasaan tidur pagi/sore hari. Penelitian ini sejalan dengan penelitian Amrieds E, dkk (2016) ada hubungan antara kebiasaan tidur pagi hingga sore dengan kejadian DBD di kelurahan 19 November Kecamatan Wundulako Kabupaten Kolaka Tahun 2016 ( $\mathrm{p}<0,05$ ). Sejalan dengan penelitian Abdullah A, dkk (2010) kebiasaan tidur pagi hingga sore hari berhubungan dengan kejadian DBD di Kab. Jeneponto ( $p<0,05)$. Kebiasaan tidur pagi/sore hari berpengaruh terhadap terjadinya kejadian DBD. Hal ini disebabkan Kebiasaan tidur pagi/sore hari biasanya dilakukan oleh anak-anak sangat merugikan kesehatan. Kebiasaan nyamuk aedes aegypti menggigit pagi hari hingga sore hari saat penghuni rumah tidur siang meningkatkan risiko untuk terkena penyakit DBD dimana biasanya nyamuk betina mencari mangsanya pada siang hari. Aktivitas menggigit biasanya mulai pagi sampai petang hari dengan 2 puncak aktivitas antara pukul 09.00-10.00 dan 16.00-17.00. Aedes mempunyai kebiasaan mengisap darah berulang kali dalam satu siklus gonotropik untuk memenuhi lambungnya dengan darah. Dengan demikian nyamuk ini sangat efektif 
sebagai penular penyakit DBD (Depkes RI, 2005).Oleh karena itu, direkomendasikan agar mengubah poa tidur

Variabel independen yang berhubungan terbalik dengan kejadian DBD adalah variabel pendidikan. Sedangkan variabel independen yang tidak berhubungan dengan kejadian dbd adalah variabel keberadaan jentik, tanaman hias dan tanaman pekarangan, kebiasaan menggantung pakaian, kebiasaan menggunakan obat anti nyamuk dan jenis kelamin

\section{PENUTUP}

\section{Kesimpulan}

1. Variabel yang berhubungan sebab akibat dengan kejadian DBD adalah beberadaan sampah, tidak melakukan 3M, kebiasaan tidur pagi/sore hari, kawat kasa pada ventilasi dan umur :

a. Mereka yang memiliki keberadaan sampah di sekitar rumah berisiko 2,9 kali untuk menderita DBD dibandingkan dengan mereka yang memiliki keberadaan sampah di sekitar rumah (CI 95\% = 1,7505,069 ).

b. Mereka yang tidak melakukan 3M berisiko 3,7 kali untuk menderita DBD dibandingkan mereka yang melakukan 3M (CI 95\% = 2,2266,243).

c. Mereka yang memiliki kebiasaan tidur pagi/sore berisiko 1,7 kali untuk menderita DBD dibandingkan mereka yang tidak memiliki kebiasaan tidur pagi/sore $(\mathrm{CI} 95 \%=1,019-2,877)$.

d. Mereka yang tidak memiliki kawat kasa pada ventilasi berisiko 2,1 kali untuk menderita DBD dibandingkan mereka yang memiliki kawat kasa pada ventilasi (CI 95\% $=1,268-$ 3,571).

e. Mereka yang berumur $<12$ tahun berisiko 17,3 kali untuk menderita DBD dibandingkan mereka yang berumur $\geq 12$ tahun $(\mathrm{CI} 95 \%=7,889$ 38,224).

2. Variabel yang berhubungan terbalik dengan kejadian DBD adalah variabel pendidikan.

3. Tidak terdapat variabel confounding dalam penelitian ini.

\section{Saran}

1. Disarankan kepada orang tua agar anaknya menggunakan obat anti nyamuk saat beraktivitas di tempat yang banyak nyamuk dan melarang anak untuk tidak bermain ditempat yang banyak nyamuk.

2. Disarankan kepada petugas puskesmas untuk dapat membudayakan masyarakat dalam pemberantasan sarang nyamuk, dengan pembentukan kelompok desawisma. Bagi masyarakat yang di temukan jentik di rumahnya maka akan diumumkan di mesjid, sehingga terbentuklah budaya malu. Untuk warga yang tidak di temukan jentik di rumahnya selama 3 bulan maka diberi reward atau penghargaan misalnya masuk ke taman wisata alam mayang secara gratis..

3. Disarankan kepada masyarakat menyediakan tempat pembuangan sampah yang tertutup disetiap rumah. Dan untuk petugas kesehatan mengadakan penyuluhan bagaimana cara mengolah sampah yang padat dengan baik dan benar.

4. Disarankan kepada masyarakat yang belum menggunakan kawat kasa agar menggunakan kawat kasa pada setiap 
ventilasi dengan baik dan mengganti kawat kasa yang sudah berlubang dengan kawat kasa yang tidak berlubang.

5. Disarankan kepada masyarakat jika tidur saat waktu puncak gigitan untuk menggunakan obat anti nyamuk atau kelambu yang dapat mencegah gigitan nyamuk

\section{DAFTAR PUSTAKA}

Abdullah A Z, Nawi R, Sibe A. (2010). Faktor Risiko Kejadian Demam Berdarah Dengue di Kecamatan Tempe Kabupaten Wajo 2009. (Online). Jurnal MKMI. Vol. 6 No. 4.

Http://Journal.Unhas.Id/Index.Php/J mkmi/ Article/Viewfile/1040/913 diakses 05 Januari 2016).

Amrieds E, dkk. (2016). Faktor-Faktor Yang Berhubungan Dengan Kejadian Demam Berdarah Dengue (DBD) Di Kelurahan 19 November Kecamatan Wundulako Kabupaten Kolaka Tahun 2016. Jurnal Ilmiah Mahasiswa Kesehatan Masyarakat. Vol. 11 No. 3 . https://media.neliti.com/media/publi cations/184804-ID-faktor-faktoryang-berhubungan-dengan-ke.pdf

Carundeng M, dkk. (2015). Analisis FaktorFaktor Yang Berhubungan Dengan Kejadian Demam Berdarah Dengue Di Puskesmas Gogagoman Kota Kotamobagu. Jurnal Kesehatan Masyarakat. Vol. 4 No. 1. https://ejournal.unsrat.ac.id/index.ph p/kesmas/article/view/12688

Darjito E, dkk. (2008). Beberapa Faktor Risiko Yang Berpengaruh Terhadap Kejadian Demam Berdarah Dengue (DBD) Di Kabupaten Banyumas. Jurnal
Media Litbang Kesehatan. Vol XVIII No. 3 https://media.neliti.com/media/publi cations/160433-ID-beberapa-faktorrisiko-yang-berpengaruh.pdf

Departemen Kesehatan Republik Indonesia. (2005). Pencegahan dan Pemberantasan Demam Berdarah Dengue di Indonesia. Jakarta.

Dinas Kesehatan Kota Pekanbaru. (2016). Data Kasus Demam Berdarah Dengue Seluruh Puskesmas Kota Pekanbaru: Pekanbaru.

Fakhriadi R, dkk. (2015). Faktor Risiko Penyakit Demam Berdarah Dengue Di Wilayah Kerja Puskesmas Guntung Paying Kota Banjarbaru. Jurnal Publikasi Kesehatan Masyarakat Indonesia. Vol. 2 No. 1. http://ppjp.unlam.ac.id/journal/index. php/JPKMI/article/view/2703

Hasan A. (2008). Hubungan Perilaku Pemberantasan Sarang Nyamuk Dengan Kejadian Demam Berdarah Dengue Di Kota Bandar Lampung. National Public Health Journal. Vol. 2 No. http://journal.fkm.ui.ac.id/kesmas/art icle/view/276

Kementrian Kesehatan Republik Indonesia, (2016). Profil Kesehatan Indonesia Tahun 2015: Jakarta

Lumingas E, dkk. (2017). Faktor-Faktor Yang Berhubungan Dengan Kejadian Demam Berdarah Dengue Di Wilayah Kerja Puskesmas Tanawangko. Jurnal Media Kesehatan. Vol. 9 No. 3. https://ejournalhealth.com/index.php /medkes/article/view/336 
Prasetyani, R D. (2015). Faktor-Faktor yang Berhubungan dengan Kejadian Demam Berdarah Dengue. (Online). Majority. Vol. 4 No. 7, Http://Jukeunila.Com/WpContent/Uploads/2015/11/61-66$\underline{\text { Radita-Dp.Pdf diakses } 05 \text { Januari }}$ 2016).

Sitio, A. (2008). Hubungan Perilaku Tentang Pemberantasan Sarang Nyamuk dan Kebiasaan Keluarga dengan Kejadian Demam Berdarah Dengue di Kecamatan Medan Perjuangan Kota Medan Tahun 2008. Tesis. Universitas Diponegoro. Semarang. http://core.ac.uk/download/files/379/ 11716372.pdf diakses 05 Januari $\underline{2015)}$.

Umaya R. (2013). Hubungan Karakteristik Pejamu, Lingkungan Fisik Dan Pelayanan Kesehatan Dengan
Kejadian Demam Berdarah Dengue Di Wilayah Kerja Puskesmas Talang Ubi Pendopo Tahun 2012. Jurnal Ilmu Kesehatan Masyarakat. Vol. 4 No. 3

Wahyudi, H. (2015). Faktor-Faktor yang Mempengaruhi Tingginya Angka Kejadian Penyakit Demam Berdarah Dengue (DBD) di Wilayah Kerja Puskesmas Kecamatan Mandau Kabupaten Bengkalis Tahun 2015. Skripsi. STIKes Hang Tuah Pekanbaru, Pekanbaru.

Widodo, N. (2012). Faktor-Faktor Yang Berhubungan Dengan Kejadian Demam Berdarah Dengue Di Kota Mataram Provinsi Nusa Tenggara Barat Tahun 2012. Universitas Indonesia :Tesis. 